\title{
STIMULASI MEMBACA PERMULAAN ANAK USIA DINI
}

\author{
Oleh \\ Ni Gusti Ayu Made Yeni Lestari \\ Institut Hindu Dharma Negeri Denpasar \\ yeni_lestari@ihdn.ac.id
}

\begin{abstract}
This study aimed at describing how to stimulate early reading for children at an early age. Early reading is one aspect of language development that is important for children at an early age. It cannot be denied that many debates have been staged about how children at an early age may be taught to read. The real problem lies not on whether it is all right or not, but more on the readiness of the children and how it is taught. Early reading is an introduction that aims at giving basics of reading mechanism, such as the ability to associate letters with language sounds that they represent, training eye-ball movements, and the children's visual and auditory readiness. Parallel to the children's world of play, then the early reading activity should be given through a game. Playing gives the children a sense of pleasure, freedom, and satisfaction. Interesting games and the involvement of letters or words will stimulate children to acquire an early reading ability. Through early reading a child can add his or her understanding that becomes a prerequisite for his or her success.
\end{abstract}

Keywords: early reading, children at an early age, play activities

\begin{abstract}
ABSTRAK
Tujuan dari penulisan ini artikel ini adalah untuk mendeskripsikan bagaimana stimulasi membaca permulaan untuk anak usia dini. Membaca permulaan merupakan salah satu aspek pengembangan bahasa yang penting bagi anak usia dini. Tidak dipungkiri banyak terjadi perdebatan tentang apakah anak usia dini boleh diajarkan membaca. Permasalahan sebenarnya bukan terletak pada boleh atau tidaknya diberikan, tapi lebih kepada kesiapan anak dan bagaimana cara memberikannya. Membaca permulaan yang merupakan sebuah pengenalan yang diberikan kepada anak usia dini, khususnya yang telah memiliki kesiapan membaca bertujuan untuk memberikan dasar-dasar mekanisme membaca, seperti kemampuan mengasosiasikan huruf dengan bunyi-bunyi bahasa yang diwakilinya, melatih gerakan bola mata, dan kesiapan visual serta auditori anak. Sesuai dengan dunia anak yaitu bermain, maka kegiatan membaca permulaan pun seharusnya diberikan melalui bermain. Bermain memberikan anak rasa senang, kebebasan, dan kepuasan. Permainan yang menarik dan melibatkan huruf ataupun kata-kata akan merangsang anak untuk memiliki kemampuan membaca permulaan. Melalui membaca permulaan seorang anak dapat menambah wawasannya yang menjadi bekal bagi keberhasilannya
\end{abstract}

Kata kunci: Membaca permulaan, anak usia dini, kegiatan bermain 


\section{PENDAHULUAN}

Anak usia dini merupakan anak yang sedang mengalami perkembangan yang fundamental, yaitu perkembangan yang dialami sekarang sangat mempengaruhi perkembangan selanjutnya. Ibarat bangunan, untuk menciptakan bangunan yang kokoh dan berkualitas, maka harus dimulai dengan mmebuat pondasi yang kokoh dengan bahan-bahan yang berkualitas dan tukang yang handal. Demikian juga halnya untuk mengasilkan generasi yang baik dan berkualitas, maka berikanlah pendidikan sejak dini, kegiatan yang bervariasi dan menyenangkan, stimulasi yang dapat membantu anak melewati tugas-tugas perkembangannya dan menjadi pendidikan yang memahami kebutuhan anak.

Semua aspek perkembangan anak harus mendapatkan stimulasi tepat. Aspek perkembangan satu akan mempengaruhi aspek perkembangan lainnya. Slah satu aspek perkembangan anak usia dini yang juga harus mendapatkan perhatian yaitu apsek perkembangan bahasa. Bahasa membentuk dasar persepsi, komunikasi, dan interaksi harian (Stice, Bertrand and Bertrand, dalam Otto, 2015). Bahasa merupakan suatu sistem simbol yang mengkategorikan, mengorganisasi dan mengklasifikasi pikiran. Melalui bahasa seseorang dapat belajar dan mendeskripsikan dunia.

Anak dapat mengekspresikan pikirannya menggunakan bahasa. Melalui bahasa orang menangkap apa yang dipikirkan anak. Dengan berbahasa, terjadi komunikasi antar anak sehingga anak dapat menjalin hubungan dengan baik. Tidak heran bahasa dianggap sebagai salah satu indikator kesuksesan seorang anak. Anak dianggap banyak berbicara kadang merupakan cerminan anak yang cerdas. Supaya anak dapat berhasil di dalam masyarakat dan budayanya, anak-anak perlu mengembangkan kemampuan bahasa yang luas. Anak-anak menggunakan kemampuan bahasanya untuk berkomunikasi dengan lingkungannya. Kemampuan bahasa yang dimiliki anak membuat anak berpartisipasi secara efektif diberbagai kegiatan sosial.
Tidak ada satu pun standar kemampuan komunikatif yang harus diajarkan guru dan harus dicapai oleh anak. Sangat penting bagi guru untuk mengetahui bahwa anak-anak akan membutuhkan kemmapuan bahasa yang luas untuk memastikan keefektifan anak dalam berkomunikasi di berbagai situasi dan kondisi dalam hidupnya.

Salah satu bentuk kegiatan pengembangan bahasa untuk anak usia dini adalah kemampuan membaca permulaan. Kegiatan membaca permulaan dapat dikatakan masih menjadi sebuah perdebatan dalam dunia pendidikan, khususnya di TK. Merujuk pada pendapat Bruner yang menyatakan bahwa sebagian pembelajaran terpenting dalam kehidupan diperoleh dari masa kanak-kanak yang paling awal dan pembelajaran itu sebagian besar diperoleh melalui bermain (Suyadi, 2010: 198). Anak usia dini bukanlah miniatur orang dewasa. Dengan demikian seharusnya orang dewasa di sekitar anak mampu memahami dunia anak-anak. Hal tersebut dapat menjadi sebuah kritikan yang ditujukan kepada sejumlah TK tentang bagaimana mengajarkan anak usia dini membaca permulaan. Peraturan Pemerintah Indonesia No.17 pasal 69 ayat 5 menyatakan "Penerimaan peserta didik Kelas I SD/MI atau bentuk lain yang sederajat tidak didasarkan pada hasil tes kemampuan membaca, menulis dan berhitung atau tes bentuk lainnya". Mengacu pada hal di atas maka seharusnya kemampuan membaca, menulis dan berhitung permulaan di PAUD tidak diarahkan bersifat akademik. Masalah utamanya bukan kepada boleh atau tidak anak membaca permulaan, namun bagaimana cara menstimulasinya, sehingga anak-anak menganggap kegiatan belajar mereka tak ubahnya bermain, dan bahkan memang berbentuk sebuah permainan.

Anak usia dini memiliki sifat khas dalam pembelajarannya. Anak usia dini bermain dengan mengeskplorasi lingkungan dan memainkan benda-benda berdasarkan apa yang mereka temui. Secara umum anakanak belajar sambil bermain. Perkembangan anak pada tahap awal membaca juga harus disajikan dengan bermain. 


\section{PEMBAHASAN}

\subsection{Perkembangan Bahasa Anak Usia Dini}

Bahasa merupakan landasan anak untuk mempelajari hal-hal lain. Sebelum anak mempelajari pengetahuan-pengetahuan lain, ia perlu menggunakan bahasa agar dapat memperoleh pemahaman dengan baik. Dengan berbahasa, anak dapat mengembangkan kemampuan dalam bidang pengucapan bunyi, menulis, membaca yang sangat mendukung kemampuan keaksaraan di tingkat yang lebih tinggi.

Anak dapat mengekspresikan pikirannya menggunakan bahasa. Melalui bahasa orang menangkap apa yang dipikirkan anak. Dengan berbahasa, terjadi komunikasi antar anak sehingga anak dapat menjalin hubungan dengan baik. Tidak heran bahasa dianggap sebagai salah satu indikator kesuksesan seorang anak. Anak dianggap banyak berbicara kadang merupakan cerminan anak yang cerdas.

Bahasa yaitu bentuk komunikasi baik lisan maupun tulisan atau tanda yang didasarkan pada sistem simbol (Santrock, 2004:67). Hal ini sejalan dengan pikiran Suhartono ( 2005 : 8) yang menyatakan bahwa bahasa merupakan rangkaian bunyi yang melambangkan pikiran, perasaan dan sikap manusia. Berarti bahasa itu merupakan system lambang. Dengan demikian, orang dapat berpikir dan berbicara secara abstrak dan kongkrit sesuai dengan lambang yang dipikirkan.

Bahasa memberi sumbangan yang besar bagi perkembangan diri anak. Dengan bantuan bahasa, anak mampu tumbuh menjadi pribadi yang yang dapat berpikir, merasa, bersikap, berbuat, serta memandang dunia dan kehidupan seperti orang-orang disekitarnya. Manusia dituntut untuk dapat menyampaikan dan mengungkapkan pikirannya dengan bahasa yang dapat dimengerti orang lain. Kondisi ini mendorong terjadinya proses berpikir pada diri manusia. Dengan demikian bahasa selain sebagai alat komunikasi juga sebagai alat berpikir (kemendiknas, $2010: 4$ ).

Bahasa anak usia dini yaitu bahasa yang dipakai anak usia dini untuk menyampaikan keinginan, pikiran, harapan, permintaan untuk dirinya sendiri. Sehari-hari, umumnya anak menggunakan bahasa yang hanya dipahami oleh orang tua dan orang disekitarnya. Setelah sekolah anak mulai menggunakan bahasa yang dimengerti orang lain dan sekaligus ia berpikir (Suhartono, 2005 : 9). Pada usia 6 tahun, perkembangan bahasa anak mengalami ledakan yang diikuti oleh masa transisi yang dramatis, yaitu perpindahan dari ekspresi diri yang hanya bersifat oral ke eskpresi diri yang tertulis. Pada periode ini, kosa kata reseptif anak bertambah, bukan saja lewat mendengar, tetapi juga lewat membaca, dan kosa kata ekspresif anak meluas dari komunikasi lisan ke komunikasi tertulis.

Bahasa reseptif dan ekspresif anak TK telah berkembang cukup baik, anak juga telah mengembangkan kemampuan untuk bercakap-cakap. Anak mulai menyadari pentingnya bahasa, walaupun pengertiannya tentang kata-kata belum sepenuhnya berkembang. Memberikan stimulasi bahasa yang cukup dan sesuai akan mempermudah anak dalam kegiatan permainan bahasa. Anak yang pernah dibacakan buku akan dapat membedakan antara tulisan dan gambar, dan anak juga akan memahami bahwa membaca dan menulis adalah bagian dari komunikasi yang menggunakan bahasa.

Teori lain juga diungkapkan oleh Chomsky (dalam Crain, 2007: 539-540) tentang kemampuan berbahasa yang secara alami dimiliki oleh setiap anak. Ia mengatakan bahwa anak memiliki cetak biru untuk mampu menciptakan sendiri struktur mentalnya secara spontan. Anak mampu berbahasa karena secara alami anak memiliki potensi untuk berbahasa. Anak juga mampu menciptakan bentuk gramatika secara alami. Gramatika adalah sebuah sistem aturan untuk menciptakan dan memahami kalimatkalimat dengan benar. Kemampuan ini didapat anak ketika mendengarkan orang lain berbicara. Secara alami, anak menangkap sistem aturan tersebut dan mulai memahami kalimat-kalimat yang di dengar. Pada saat anak memahami sistem aturan tersebut maka pada saat itu pula anak mampu menciptakan 
kalimat-kalimat baru dengan sistem aturan yang sama. Kegiatan ini kemudian dituangkan dalam bentuk aktivitas berbicara, membaca, dan menulis.

Kemampuan berbahasa dapat dikatakan terkait erat dengan pendekatan pemerosesan informasi atau perkembangan memori. Bahasa yang diserap oleh anak masuk dalam memori jangka panjang karena dilakukan terus menerus. Anak mampu menciptakan kalimat baru yang merupakan respon dari penggabungan rangsangan yang tersimpan dalam memori. Nelson (dalam Papalia, 2008: 348), menyebutkan ada tiga memori yang ada pada diri anak, yaitu memori generic (generik), memori episodic (episodis), dan memori autobiographical (autobiografis). Memori generik berkaitan dengan peristiwa yang akrab dan terjadi berulang kali tanpa detail tempat dan waktu. Memori episodis berkaitan dengan kesadaran akan pengalaman tertentu yang terjadi pada waktu dan tempat tertentu. Memori autobiografis merujuk pada memori yang membentuk sejarah kehidupan seseorang. Memori autobiografis sangat berkaitan dengan perkembangan bahasa. Kemampuan anak untuk menyimpan katakata ke dalam memori, merenungkan dan membandingkannya. Perolehan kosa kata dan percakapan yang dilakukan dengan anak atau yang ada di sekitar anak tersimpan dalam memori autobiografis sehingga sampai kapanpun memori itu tetap ada. Memori akan tetap ada jika itu merupakan keunikan dari suatu peristiwa dan ada partisipasi aktif baik dalam peristiwa itu atau dalam menceritakan kembali.

Perkembangan bahasa pada anak meliputi empat kemampuan yaitu kemampuan mendengar, berbicara, membaca, dan menulis. Menurut Kostelnik, et.al (2007: 307), tujuan pengembangan bahasa untuk anak usia dini adalah agar anak mampu mengkomunikasikan ide dan perasaan serta mampu mengintepretasikan komunikasi yang diterimanya. Dari pendapat tersebut dapat dinyatakan bahwa fungsi bahasa yang utama adalah sebagai alat komunikasi. Anak-anak memperoleh kemampuan berbahasa dengan cara yang sangat menakjubkan. Menurut Suyadi (2010: 96), "pada akhir masa dininya, rata-rata anak telah menyimpan lebih dari 14.000 kosa kata". Pada perkembangan selanjutnya, anak mampu menambah kosa kata secara mandiri dalam bentuk komunikasi yang baik. Kemampuan tersebut lebih ditegaskan pula oleh Papalia, et.al., yang membahas lebih spesifik tentang tentang kemampuan berbicara pada anak usia dini tersebut. Menurutnya, kamampuan bicara anak pada usia 5-7 tahun sudah mampu melakukan percakapan seperti orang dewasa. Anak berbicara dengan kalimat yang lebih panjang dan lebih kompleks, banyak menggunakan kata sambung dan preposisi. Namun, menurut Papalia (2008: 342) anak belum menguasai titik kefasihan bahasa. Anak yang belum terlalu fasih menguasai bahasa akan terlihat jarang dalam menggunakan kalimat pasif.

Pengembangan kemampuan lain dari bahasa adalah kemampuan membaca. Kemampuan ini berbeda pada masingmasing anak. Menurut Owens (2012: 360), "reading is the synthesis of a complex network of perceptual and cognitive act from word recognition and decoding skills to comprehension and integration". Dengan demikian membaca adalah aktivitas belajar yang dominan memerlukan indera visual dan juga melibatkan fungsi penginderaan lain di otak. Pengembangan bahasa terakhir adalah kemampuan menulis. Kemampuan menulis anak-anak mengikuti urutan perkembangan. Kemampuan ini muncul dari coretan-coretan sebelumnya dan pertama-pertama tersebar secara acak di seluruh halaman, karateristik ini mencerminkan pemahaman yang tidak lengkap tentang batas-batas kata dan juga ketidakmampuan menciptakan satu baris dalam pikiran untuk menempatkan hurufhuruf. Anak-anak menemukan ejaan dengan melakukan penilaian tentang bunyi dan dengan menghubungkan bunyi yang mereka dengar dengan huruf yang mereka kenal. Snow (dalam Slavin, 2008: 95) menjelaskan dalam mencoba untuk menunjukkan apa yang didengar, anak biasanya menggunakan 
nama-nama huruf alih-alih bunyi huruf; vokal pendek sering dihilangkan karena tidak langsung berhubungan dengan nama-nama huruf. Pada dasarnya anak memiliki tahap yang berbeda-beda dalam menulis sesuai dengan kematangannya. Untuk kematangan kemampuan menulis, selain aspek kognitif, dari aspek motorik juga diperlukan yaitu motorik halus. Aspek ini berperan untuk membantu anak mengkoordinasikan mata dan tangannya dalam menulis.

Berdasarkan karakteristik aspek perkembangan yang telah dijabarkan tersebut, masing-masing aspek tidak dapat berdiri sendiri. Kognitif anak sangat berperan dalam pengembangan bahasa, motorik, dan sosial. Demikian pula aspek lain sangat berpengaruh satu sama lain. Keterlibatan pada masing-masing aspek mencetuskan bahwa pendidikan untuk anak usia dini tidak dapat dilakukan secara terpisah-pisah namun harus menjadi satu-kesatuan.

\subsection{Membaca Permulaan Anak Usia Dini}

Merujuk pada pendapat Aisyah (2008), kebanyakan anak usia TK berada pada "gerbang" menjadi pembaca. Pada usia ini anak pada umumnya membaca dengan melihat tulisan, tetapi anak sering bergantung pada ingatan mengenai cerita dan pada gambar. Pada akhir masa TK, sebagian besar anak dapat mengenali dan dapat membedakan huruf besar dan huruf kecil. Anak juga dapat belajar bunyi berhubungan dengan sebagian besar huruf-huruf dalam abjad. Menurut Tim Seldin (2007: 175), "pada usia berapapun anak memperlihatkan minatnya untuk membaca, maka guru maupun orang tua harus mulai mengajarkan cara membaca". Jika sudah siap, anak akan menyerap semuanya untuk mulai membaca serta menulis sendiri.

Menurut Cochren (dalam Aulia, 2011: 28-29), tahapan membaca terbagi atas lima tahapan yaitu tahapan fantasi (magical stage), tahapan pembentukan konsep diri (self conceft stage), tahap membaca gambar (bridging reading stage), tahap pengenalan bacaan (take-off reader stage), dan tahap membaca lancar (independent reader stage). Pada tahap fantasi. Anak mulai belajar menggunakan buku, berpikir bahwa buku itu penting dengan cara membolak-balikan buku. Terkadang, anak suka membawabawa buku kesukaannya. Tahap kedua adalah tahap pembentukan konsep. Pada tahap ini anak memandang dirinya sebagai pembaca dan mulai melibatkan dirinya dalam kegiatan membaca dan pura-pura membaca buku. Tahap ketiga adalah tahap membaca gambar. Anak menyadari cetakan yang tampak dan mulai dapat menemukan kata yang sudah dikenal, dapat mengungkapkan kata-kata yang memiliki makna dengan dirinya, dapat mengulang kembali cerita yang tertulis, dapat mengenal cetakan kata dari puisi atau lagu yang dikenalnya, serta sudah mengenal abjad. Tahap keempat yaitu anak mulai menggunakan tiga sistem isyarat (graphoponic, semantic dan syntactic) secara bersama-sama. Anak mulai tertarik pada bacaan dan mulai membaca tanda-tanda yang ada di lingkungan seperti membaca kardus susu, pasta gigi dan lain-lain. Tahap terakhir membaca menurut Cochran adalah tahap membaca lancar. Pada tahap ini anak dapat membaca berbagi jenis buku secara bebas.

Salah satu faktor yang sangat penting bagi anak agar siap membaca adalah kemampuan bahasa lisan yang baik. Anakanak dengan bekal kosa kata yang kaya dan bisa berekpresi dengan bebas cenderung dapat membaca dengan lebih baik. Kesiapan membaca dan menulis pada anak usia dini seharusnya memberi kesempatan untuk: (1) menggunakan kemampuan bahasanya untuk menceritakan kembali, (2) mengenali bentuk kata, (3) mengenali bahwa sebuah cerita ada permulaan, tengah, dan akhir, dan (4) mempelajari kosa kata baru.

Membaca merupakan sebuah proses berpikir, bukan respon otomatis untuk menulis. Vygotsky (dalam Rasyid, 2009: 132) mengatakan bahwa perkembangan bahasa dan intelektual anak usia dini mencakup bagaimana mengaitkan bahasa dengan pikiran. Hal tersebut adalah proses perkembangan individualistik. Menurut 
Sonawat \& Jasmine (2007: 41), “membaca adalah salah satu petualangan paling menggairahkan dan kepuasan emosional dari anak usia dini". Lingkungan membaca lebih jauh dapat meningkatkan motivasi anak-anak. Belajar membaca membutuhkan waktu, kesabaran, keinginan, dan kesiapan. Anak-anak yang menikmati gambar, alfabet, memupukkan sajak dan buku cerita dari awal masa bayi akan memiliki keinginan yang besar untuk membaca.

Seperti yang diungkapkan oleh Essa (2011: 371), bahwa:

"Many children have had happy experiences with books all of their lives. They approach book, reading activities anticipating enjoyment; they also have developed the concentration and attention required for full involvement. Others may not have had many such opportunities and many need some individual, more intimate story reading time to help them acquire a greater appreciation for books."

Banyak anak-anak memiliki pengalaman yang senang dengan buku dalam kehidupan mereka. mereka tertarik dengan buku, menikmati kegiatan membaca, mereka juga telah mengembangkan konsentrasi dan perhatian yang diperlukan untuk keterlibatan penuh. Orang lain mungkin tidak memiliki banyak kesempatan seperti itu dan banyak membutuhkan bantuan orang lain. Munculnya begitu banyak buku bagus yang tersedia untuk anak-anak memberikan kekayaan cara untuk berkontribusi pengalaman bahasa, memperkuat konsep, menghibur, merangsang pemikiran, dan juga dukungan emosional.

Beberapa teknik membantu melibatkan anak dalam proses membaca buku. Untuk satu hal, guru memainkan peran penting dalam bagaimana anak-anak menanggapi pembacaan cerita. dalam arti, anak mendukung cerita melalui antusiasme mereka, minat dalam animasi atau gambar yang ada dalam buku cerita.

Jeane Chall (dalam Aulia, 2011: 3132) mengemukakan bahwa belajar membaca mencakup pemerolehan kecakapan yang dibangun pada keterampilan sebelumnya. Untuk mencapai hal tersebut ada lima tahapan dalam perkembangan kemampuan membaca, dimulai dari keterampilan prereading hingga ke kemampuan membaca yang sangat tinggi pada orang dewasa, yaitu: (1) Tahap dasar (0), (2) Tahap 1, (3) Tahap 2, (4) Tahap 3, dan (5) Tahap 4. Tahap dasar (0) ditandai ketika anak mulai menguasai prasyarat membaca, dan setelah masuk sekolah anak dapat membedakan huruf dalam alfabet. Selanjutnya, pada saat lain anak sudah dapat "membaca" beberapa kata, yang menjadi simbol-simbol populer yang sering disaksikan di televisi atau media lainnya. Pada tahap 1 anak belajar kecakapan merekam fonologi. Kecakapan fonologi ini digunakan untuk menerjemahkan simbolsimbol ke dalam suara dan kata-kata. Tahap 2, selanjutnya kebanyakan anak sekolah sudah menguasai hubungan dari huruf ke suara dan dapat membaca sebagian besar kata dan kalimat sederhana yang diberikan. Pada tahap 3, terdapat istilah "learning to read" menuju "reading to learn". Tahap ini anakanak sudah bisa mendapatkan informasi dari materi yang tertulis, dan hal ini direfleksikan dalam kurikulum sekolah. Terakhir adalah tahap 4, pada tahap ini anak semakin dapat memahami beragam materi bacaan dan menarik kesimpulan dari apa yang mereka baca.

Membaca bukan sekedar membaca sepintas saja, tetapi membaca harus melibatkan pikiran untuk memaknainya. Membaca sebagai aktivitas belajar yang dominan memerlukan indera visual sekaligus melibatkan fungsi penginderaan lain di otak. Ada empat kemampuan yang diperlukan untuk dapat membaca, yaitu: (1) mengenal bentuk, (2) mengenal perbedaan bunyi huruf, (3) mengenal rangkaian (pola), dan (4) mengenal perbedaan intonasi (Kemdiknas, 2010). Keempat kemampuan tersebut merupakan suatu rangkaian yang tiap tingkatannya memiliki kekuatan untuk berlanjut ke tingkatan yang berikutnya.

Menurut Drouin, et all. (2006), untuk dapat membaca sebuah abjad sebagai suatu bahasa, maka anak harus mengenali huruf terlebih dahulu. Anak-anak harus tahu dan menggunakan perbendaharaan kata- 
kata dasar yang baik. Anak hanya dapat memahami kata-kata yang mereka lihat tercetak jika mereka telah menemui katakata tersebut dalam pembicaraan. Anak-anak yang dapat berbicara dengan baik dan banyak membaca cenderung menjadi pembaca yang baik pula. Berdasarkan uraian di atas, kemampuan membaca permulaan adalah suatu kemampuan yang dimiliki oleh anak usia dini untuk membaca simbol, huruf, kata dan kalimat sederhana yang menghubungkan bahasa lisan dengan tulisan. Anak usia dini memiliki potensi untuk menjadi pembaca yang baik.

\subsection{Stimulasi Membaca Permulaan Anak Usia Dini}

Kemampuan membaca permulaan bukanlah salah satu prasyarat anak untuk mengikuti tes masuk SD. Membaca permulaan merupakan suatu pengenalan kepada anak bagaiamana menterjembahkan simbol tulis ke dalam bunyi. Melalui pengenalan membaca yang diberikan sejak usia dini dapat memberikan anak bekal untuk menguasai berbagai bidang studi di pendidikan selanjutnya.

Kemampuan membaca permulaan dapat dikuasai anak apabila diberikan stimulasi sedini mungkin secara tepat dan tanpa ada unsur paksaan. Tepat dalam arti sesuai dengan karakteristik dan tahapan perkembangan sesuai dengan usia anak dan tanpa ada unsur paksaan berarti kegiatan membaca permulaan dilakukan anak dengan rasa senang dan bebas.

Stimulasi yang dapat memberikan anak rasa senang dan bebas adalah melalui kegiatan bermain. Bermain merupakan faktor penting dalam kegiatan pembelajaran dan esensi bermain harus menjadi jiwa dari setiap kegiatan pembelajaran anak usia dini (Suyanto, 2005: 114). Bermain dan pembelajaran anak usia dini adalah dua hal yang tidak bida dipisahkan dan memang pembelajaran di anak usia dini dilakukan melalui bermain.

Kegiatan bermain paling digemari oleh anak-anak pada masa prasekolah, dan sebagian waktu anak digunakan untuk bermain sehingga ada ahli yang berpendapat bahwa usia prasekolah adalah usia bermain (Tedjasaputra, 2001: 38). Dari penelitian yang dilakukan oleh para ilmuwan, diperoleh temuan bahwa bermain mempunyai manfaat yang besar bagi perkembangan anak. Bermain merupakan pengalaman belajar yang sangat berguna untuk anak, misalnya saja memperoleh pengalaman dalam membina hubungan dengan sesama teman, menambah perbendaharaan kata, menyalurkan perasaan-perasaan tertekan. Teori kognitif dan juga pandangan teori mutakhir menunjukkan bahwa bermain sangat bermanfaat bagi pertumbuhan anak. Karena itu, tidak ada alasan bagi orang tua, pengasuh dan juga guru TK untuk melarang anak bermain. Barmain merupakan hak anak yang harus dihormati, karena bermain merupakan kegiatan yang berguna dantidak hanya membuang-buang energi saja. Melalui aktivitas bermain anak dapat dimanfaatkan untuk membantu mengembangkan berbagai aspek perkembangan anak, termasuk kemampuan membaca permulaan (Suratno, 2005: 80).

Selain itu, memberikan lingkungan yang kaya bahasa atau aksara akan dapat memotivasi anak untuk belajar membaca permulaan. Orangtua maupun guru dapat membuat berbagai gantungan huruf ataupun kata di dinding ruangan, memberi label pada barang-barang yang sering digunakan oleh anak, ataupun berkreasi membuat media bermain yang dapat dimainkan bersama anak. Stimulasi yang terarah dan teratur akan menghantarkan anak ke gerbang pembaca.

\section{PENUTUP}

Bahasa merupakan salah satu aspek perkembangan anak yang sangat berpengaruh terhadap kemampuan anak dalam bersosialisasi. Melalui sosialiasi atau berinteraksi degan lingkungan, anak dapat mengembangkan pengetahuan dan wawasannya. Kemampuan bahasa anak usia dini meliputi kemampuan berbicara, menyimak, membaca dan menulis permulaan. Keempat kemampuan tersebut 
saling berkaitan dalam mempersiapkan anak mengenal dunia melalui bahasa. Membaca merupakan salah satu bentuk kemampuan berbahasa reseptif. Kemampuan membaca permulaan yang dimiliki oleh anak usia dini akan memungkinakan anak mampu melatih kemampuan kognitifnya. Membaca merupakan sebuah proses berpikir, bukan respon otomatis untuk menulis. Vygotsky (dalam Rasyid, 2009: 132) mengatakan bahwa perkembangan bahasa dan intelektual anak usia dini mencakup bagaimana mengaitkan bahasa dengan pikiran.

Mempersiapkan anak menjadi pembaca bukan merupakan hal yang dipaksakan. Anak akan tertarik membaca apabila distimulasi dengan tepat dan terarah serta sesuai dengan kemampuan yang ditunjukkan oleh anak. Seperti yang diungapkan oleh Siantayani (2011: 10), "kesiapan dalam membaca tidak terlepas dari dua unsur utama yaitu kesiapan neural dan kesiapan muscular". Kesiapan neural adalah kondisi kematangan anak secara neurologis, yaitu kemampuan untuk mulai dapat mengenal prasyarat membaca. Sedangkan kesiapan muskular adalah kesiapan anak dalam bidang koordinasi otototot untuk menggerakkan organ-organ yang diperlukan untuk membaca.

Stimulasi membaca permulaan untuk anak usia dini haruslah berpedoman pada konteks bagaimana anak usia dini belajar. Dunia anak adalah dunia bermain. Dengan demikian konteks stimulasi membaca permulaan haruslah dilakukan melalui kegiatan bermain yang bervariasi dan menyenangkan. Selain itu, orangtua maupun guru juga harus menstimulasi dengan memberikan anak lingkungan yang kaya bahasa atau aksara. Tanpa disadari anak akan belajar mengenai huruf, kata maupun bunyi huruf tersebut cara yang menyenangkan. Kunci utama keberhasilan yang mengantarkan anak menuju gerbang pembaca adalah stimulasi yang yang diberikan sesuai dengan karakteristik dan kemampuan anak serta cara yang dituganakan bervariatif dan menyenangkan.

\section{DAFTAR PUSTAKA}

Aisyah, Siti dkk,. 2008. Perkembangan dan Konsep Dasar Pengembangan Anak Usia Dini. Jakarta: UT.

Aulia. 2011. Mengajarkan Balita Anda Membaca: Revolusi Cerdas Untuk Kemampuan Anak Membaca Di Rumah. Yogyakarta: Intan Media.

Crain, William. 2007. Teori Perkembangan: Konsep dan Aplikasi, Alih Bahasa oleh Yudi Santoso. Yogyakarta: Pustaka Pelajar.

Drouin, Michelle et. al. 2006. "Alphabet Knowladge in Preschool: A Rasch model analysis". University of Wollongong Library. http:// www. sciencedirect. com. ezproxy. uow.edu.au/science/ article/ pii/ $\underline{\text { S0885200611000998 (diakses tanggal } 9}$ September 2012).

Essa, Eva. L. 2011. Introduction To Early Childhood Education Six Edition. Belmont: Wadsworth.

Kemdiknas. 2010. Pengembangan Konsep Pengetahuan Bahasa. Jakarta: Kemdiknas.

. Peraturan Pemerintah Republik Indonesia Nomor 17 Tahun 2010 tentang Pengelolaan dan Penyelenggaraan Pendidikan.

. Pengembangan Konsep Pengetahuan Bahasa. Jakarta: 2010.

Kostelnik, Marjorie J., Anne K. Soderman, Alice P. Whiren. 2007. Developmentally Appropriate Curriculum Fourth Edition. USA: Pearson, 2007..

Otto, Beverly. 2015. Perkembangan Bahasa Pada Anak Usia Dini. Jakarta: Kencana.

Owens, Robert, E. 2012. Language Development: An Introduction. USA: Pearson. 
Papalia, Diane E., et.al. 2008. Human Development, Alih Bahasa A. K. Anwar. Jakarta: Kencana, 2008.

Rasyid, Harun dkk. 2009. Asesmen Perkembangan Anak Usia Dini. Yogyakarta: Multi Pressindo.

Santrock, John W. 2004. Life Span Development (Perkembangan Masa Hidup), Edisi kelima, jilid 1. Jakarta: Erlangga.

Siantayani, Yulianti. 2011. Persiapan Membaca Bagi Balita (Yogyakarta: Krizter Publisher.

Suhartono. 2005. Pengembangan Keterampilan Berbicara Anak Usia Dini.Departemen Pendidikan Nasional Direktorat Jendral Pendidikan Tinggi Direktorat Pembinaan Pendidikan Tenaga Kependidikan dan Ketenagaan Perguruan Tinggi.

Slavin, Robert E. 2008. Psikologi Pendidikan: Teori dan Praktik, Alih Bahasa oleh Marianto Samosir. Jakarta: Indeks.

Sonawat, Reeta \&, Jasmine Maria Francis. 2007. Language Development For Preschool Children. Mumbai: Abhinav Enterprises.

Suyadi. 2010. Psikologi Belajar PAUD. Yogyakarta: Pedagogia.

Suyanto, Slamet. 2005. Dasar-Dasar Pendidikan Anak Usia Dini.Yogyakarta: Hikayat Publishing.

Suratno. 2005. Pengembangan Kreativitas Anak Usia Dini. Jakarta: Departemen Pendidikan Nasional Direktorat Jendral Pendidikan Tinggi Direktorat Pembinaan Pendidikan Tenaga Kependidikan dan Ketenagaan Perguruan Tinggi.

Tedjasaputra, Mayke. S. 2001. Bermain, Mainan dan Permainan untuk Pendidikan Anak Usia Dini. Jakarta: Grasindo.
Tim Seldin. 2007. Membesarkan Anak Hebat dengan Metode Montessori . Jakarta: Gaya Pvorit Press. 